\title{
OREGON JUNCO AT ISLAND LAKE, MANITOBA
}

by $A$. Edward Wilson, Island Lake, Manitoba

In the fall of 1967 I banded 207 Slate-colored Juncos (Junco hyemalis) at Island Lake. Four late arrivals fed under my feeder from October 22 to October 28. On the 29th, I noticed that one of the four seemed to be slightly different. I spent some time observing the bird and finally concluded that it was either an Oregon Junco (Junco oregonus) or a hybrid between an Oregon Junco and a Slatecolored Junco. I hastily set up my mist nets on top of the snow and almost immediately captured the bird. According to W. Earl Godfrey, The birds of Canada (1966: 389-90), the hood of the Oregon Junco stops short of the brown on the sides, a feature that was apparent in the bird I had captured. I then sent the live bird in a cage by air to Dr. Robert Nero, Manitoba Museum of $\mathrm{Man}$ and $\mathrm{Na}$ ture, Winnipeg, who agreed that the bird appeared to be an Oregon Junco. This identification was confirmed by W. Earl Godfrey, National Museum of Canada, Ottawa, who identified it as Junco oregonus montanus. This is a subspecies of the Oregon Junco which breeds in the interior of British Columbia and western Alberta. Island Lake is about 300 miles north-northeast of Winnipeg and about 1000 miles northeast of the nearest known breeding range of this species. This is the northernmost locality for which the Oregon Junco has been reported in Manitoba. The specimen, an adult male, is in the Manitoba Museum collections 1.2-2510).

\section{VARIED THRUSH AT ROSETOWN, SASKATCHEWAN} by Wayne Renaud, Rosetown, Saskatchewan

Thanksgiving day, October 9, 1267 was an unusual day for me, because of an unexpected abservation of a straggler from the Rockies, the Varied Thrush (Ixoreus naevius). I was gazing out of our porch window at the overcast sky and the garden, bare of all plants at this season, when I caught sight of a bird in the far corner. At first I thought it was a Robin; from a distance its actions were very similar to those of this well-known bird of lawn and garden. But as it came closer I became aware of the black stripe across its breast, a narrow orange stripe above both eyes, and two light orange wing bars. I knew then it was definitely not a Robin, but because of its actions I was sure it must be a member of the Thrush Family. But which one?

The bird kept coming closer, hopping on both feet in the manner of a Robin, until it was only 10 or 15 feet from the window. My curiosity was getting the better of me, and I wanted to go at once for a bird guide, but I watched the bird until it finally flew off.

In my guide books later I found that the bird was a Varied Thrush which inhabits the Rocky Mountains from Alberta to California. I also learned that it was a rare straggler in Saskatchewan, and so I knew that I had seen one of the rarest of our birds right in my own back yard. I wrote to Doug Gilroy, who writes the "Prairie Wildlife" column in the Western Producer, and he agreed with my identification.

The following day I saw the bird again in the garden while I was waiting for the school bus, but after that I never saw it again. However, I shall not forget this remarkable observation.

[EDITOR'S NOTE: The status of the Varied Thrush in Saskatchewan has 
been regarded as hypothetical (Field check-list of Saskatchewan birds, 4th ed., 1959). However, there have been a number of sight observations in recent years, most of which have already been recorded in the Blue Jay in articles by Belcher (Blue Jay, 22:153, December, 1964) and Brazier (Blue Jay, 23:160, December, 1965). These include a record of a bird banded at Burnham, Saskatchewan on September 27, 1949 by Arthur Ward, and several sight records for Regina city. In Regina, one was seen September 9,1958 by Margaret Belcher; one on September 30, 1961 by Mrs. Elsie
Cheseman; one on May 22, 1962 by Herb Tempel; one on October 24, 1964 by Belcher and others; one on October 12, 1965 by Frank Brazier and again on the following day by R. W. Nero, J. Gerrard and Belcher, with a further observation (possibly of a second bird) by Belcher on October 23 and Brazier on October 24, 1965; one on October 1, 1966 by F. G. Bard and F. W. Lahrman. Because of this concentration of records in Regina, it is of interest to have a report from Rosetown. Wayne Renaud is a 15-year-old student of birds who has been contributing to the Junior Naturalists.]

\section{RUSTY BLACKBIRD ATTACKS SPARROWS}

\section{by $A$. Edward Wilson, Island Lake, Manitoba}

An observation of Rusty Blackbirds (Euphagus carolinus) killing and feeding on Common Snipe and Robins when hard pressed for food following a heavy snowstorm has been quoted in Bent (1958. Life histories of North American blackbirds, orioles, tanagers, and allies. U.S. Natl. Mus. Bull. 211, p. 291). This strange behaviour was seen in Texas in 1895: “ ... I saw them actually kill ten or twelve Snipe on the ground where the snow had melted, but there were thirty or forty dead ones that I saw in other places. The Rusty Blackbirds were the principal aggressors, and it was astonishing to see how quickly they could attack and lay out a Snipe or a Robin. Both species were killed while on the ground and the Blackbirds would only eat the head, or as near as I could see, the brain, while the body was left untouched."

Brief observations of related behaviour made by me this spring at Island Lake in northern Manitoba provide further evidence of the predatory aggressiveness of this species. On May 17, 1968, after a three-day snowfall during which food was virtually impossible to find, approximately 200 sparrows and several
Rusty Blackbirds and Red-winged Blackbirds fed under my feeder during the daylight hours without intermission. Shortly after 7:00 p.m. a male Rusty Blackbird pounced on a White-throated Sparrow, seizing it in its claws, and a wild struggle ensued during which the blackbird pecked furiously at the sparrow's head. Before the sparrow could be killed the blackbird was frightened off. The other birds scattered at the beginning of the attack, obviously agitated, but too hungry to go far. For some time afterwards the attacker was given an area of several square feet to himself. However, he made at least two more lunges at White-throated Sparrows and one at another male Rusty Blackbird. Earlier on the same day, Miss La Nore Morehouse and Miss Constance Singleterry reported seeing a Rusty Blackbird attack a sparrow which they could not identify. Enos Legge reported two other attacks, again on unidentified sparrows.

On May 18, no attacks were observed, but a decapitated Whitethroated Sparrow was found about 40 feet west of my feeder. It seems probable that this is a fifth instance of a Rusty attack. 